\title{
外科域に怙ける重症細菌感染症に対する静注用人免疫グロブリン （SM-4300）と抗生剂との併用効果
}

SM-4300研究会代表者

酒 井克 治

(昭和59年 8 月 27 日受付)

(昭和59年 9 月 18 日受理)

\section{Key words : SM-4300, Human Immunoglobulin, Clinical Trial, Severe Infection, Surgery}

\begin{abstract}
要旨
新規非修飾型静注用乾燥イオン交換樹脂処理人免疫グロブリン製剤 SM-4300 と抗生剂との併用効果 扣よび安全性と有用性について検討し, SM-4300は外科領域に拈ける重症細菌感染症に対して, 抗生剂と 併用して, その臨床効果ならびに細菌学的効果が期待され, 安全かつ有用な静注用人免疫グロブリン製 薬であると考兄られる結果を得た。

対象は昭和 57 年 12 月から昭和 59 年 3 月までに全国35施設に入院した重症細菌感染症患者で, 3 日以上 の抗生剤療法による治療効果が不充分かあるいは認められなかった153例に SM-4300が投与された.

主治医判定の評価対象は129例で，著効12例（9.3\%)，有効44例（34.1\%)，やや有効39例 $(30.2 \%)$, 無効 34 例 (26.4\%) であり，有効以上の有効率は $43.4 \%$ で，やや有効を含めると $73.6 \%$ 有効率であっ た.

判定委員会に括ける採用症例は82例で, 著効 8 例 (9.8\%), 有効 37 例(45.1\%), やや有効 21 例 (25.6\%), 無効16例 (19.5\%) であり，有効率は $54.9 \%$ で，やや有効を含めると $80.5 \%$ 市った。また，これらの らち, 細菌学的効果を検討乙得た症例は52例で, 分離菌別細菌学的効果は57株中菌消失 22 株 $(38.6 \%)$, 菌減少 8 株 (14.0\%), 不変 27 株 $(47.4 \%)$ であった。

判定委員会採用症例について, 基礎疾患の種類, 感染症の種類, 原因菌の種類ならびに SM-4300の投 与量拉よび投与回数と臨床効果の関係について検討したが，一定の傾向は認められなかった.

副作用については，SM-4300の投与された全153例のうち，自・他覚的副作用の発現した例はなく, 臨 床検査值異常は 3 例 $(2.0 \%)$ 飞認められたが，いずれも臨床上問題と考兄られるものはなかった。
\end{abstract}

\section{I. 緒 言}

人免疫グロブリンは，細菌，ウイルス拉よび原 虫に対し幅広い抗体を有して抒り，低抒よび無ガ ンマグロブリン血症执よび重症感染症に対する抗 生物質との併用に拈いて有用性が認められてい る $^{1) \sim 4)}$.

人免疫グロブリン製剂は，最初筋注用製剂が用 いられたが，注射局所の痛み，投与量の限界，投

別刷請求先：（宁545）大阪市阿倍野区旭町 1-4-54 大阪市立大学医学部外科学第 II 教室

酒井 克治
与量の約 $50 \%$ が組織中の蛋白分解酵素により失活 すること，拉よび投与部位から血管系への移行に 時間を要することなどの欠点があり ${ }^{5)}$, 静注用人 免疫グロブリン製剂が切望された。また，筋注用 製剂に含まれる大分子の凝集体によるアナフィラ キシー様の重篤な副作用が発現することが知ら $れ^{677)}$, 安全かつ有効な静注用人免疫グロブリン製 剤の研究が進められ, ペプシン処理人免疫グロブ リン,プラスミン処理人免疫グロブリン, スルホ化人 免疫グロブリンなどの各製剂が開発された ${ }^{8) ~ 11) . ~}$ しかし, 酵素処理した製剤は静注後の半減期が短 
かく，かつ Fc 活性の喪失のためグロブリンの機 能が不充分となる欠点があり，スルホ化した製剤 には Fc 活性回復に時間を要するなどの欠点があ った。ついでこれら変形を受けない(intact) 人免 疫グロブリンとしてポリエチレングリコール処理 により大分子の㠜集体を除去した製剤が開発さ れ，既に広く沉用されている12) 14).

SM-4300は，米国トラベノール社ハイランド事 業部に扔いて開発された新規乾燥イオン交換樹脂 処理静注用人免疫グロブリン製剂で，Cohn の低 温エタノール分画法 ${ }^{15)}$ とって得られたガンマグ ロブリン画分をイオン交換樹脂 DEAE七ファデ ックスで処置することにより，大分子の凝集体を
除去して扣り，ペプシンやプラスミンで処理した 分屑でなく，またスルホ化等の化学修飾を受けて いない，即ち変形を受けない自然の (intact) ガン マグロブリン製剤で，総蛋白から添加した人血清 アルブミンを除いた量の $90 \%$ 以上が7SIgGより なる。交た本剤の抗補体作用は，20単位 $\left(\mathrm{CH}_{50}\right)$ 以下で，理想的で安全かつ有効な静注用製剤であ るといえる16) 18).

今回, SM-4300研究会(外科領域)では, 同一プ ロトコールによる多施設共同研究により，外科領 域に扣ける重症細菌感染症を対象として, 抗生剂 との併用療法に括けるSM-4300の治療効果抢よ び安全性と有用性を検討し，一応の評価を得たの

Table 1 The member institutes and coworkers of the society for clinical investigation on SM-4300

\begin{tabular}{|c|c|}
\hline Institutes & Doctors \\
\hline $\begin{array}{l}\text { The Third Department of Surgery, Nihon University, } \\
\text { School of Medicine }\end{array}$ & Issei Nakayama \\
\hline Department of Surgery, Tokyo Second National Hospital & Masaki Arimori, Toshiyuki Ikeuchi \\
\hline $\begin{array}{l}\text { The First Department of Surgery, Nagoya City University, } \\
\text { School of Medicine and Related Institutes }\end{array}$ & $\begin{array}{l}\text { Jiro Yura, Nagao Shinagawa, } \\
\text { Tetsuro Takaoka, Akishige Nakamura } \\
\text { Osamu Yoshimi, IKuro Fukumoto }\end{array}$ \\
\hline $\begin{array}{l}\text { The Second Department of Surgery, Kyoto University, } \\
\text { School of Medicine }\end{array}$ & Takashi Inamoto \\
\hline $\begin{array}{l}\text { The Second Department of Surgery, Osaka City University, } \\
\text { School of Medicine and Related Institutes }\end{array}$ & $\begin{array}{l}\text { Katsji Sakai, Mikio Fujimoto, } \\
\text { Takami Ueda, Keinosuke Matsumoto, } \\
\text { Yuzuru Morimoto, Susumu Doi, } \\
\text { Takeya Sasaki, Kiyoshi Mitsuyoshi }\end{array}$ \\
\hline Department of Surgery, Reserch Institute for Microbial & Tetsuo Taguchi, Jun Ota, \\
\hline Diseases, Osaka University and Related Institutes & $\begin{array}{l}\text { Takashi Okumura, Kazuyoshi Tomita, } \\
\text { Masaharu Kimura }\end{array}$ \\
\hline $\begin{array}{l}\text { The First Department of Surgery, Kyushu University, } \\
\text { School of Medicine }\end{array}$ & $\begin{array}{l}\text { Fumio Nakayama, Kiyokazu Toyoda, } \\
\text { Hideaki Ito }\end{array}$ \\
\hline $\begin{array}{l}\text { The First Department of Surgery, School of Medicine, } \\
\text { Nagasaki University and Related Institutes }\end{array}$ & $\begin{array}{l}\text { Masao Tomita, Hiroyoshi Ayabe, } \\
\text { Kyoichi Noguchi, Masumi Ifuku, } \\
\text { Hiroya Ishimaru }\end{array}$ \\
\hline $\begin{array}{l}\text { The Second Department of Surgery, School of Medicine, } \\
\text { Nagasaki University }\end{array}$ & $\begin{array}{l}\text { Ryoichi Tsuchiya, Kensuke Yamamoto, } \\
\text { Nobuo Mochinaga }\end{array}$ \\
\hline $\begin{array}{l}\text { The First Department of Surgery, Kumamoto University, } \\
\text { School of Medicine and Related Institutes }\end{array}$ & $\begin{array}{l}\text { Yoshimasa Miyauchi, Takehisa Hiraoka, } \\
\text { Norio Ohtsuka, Yoshihide Hasegawa, } \\
\text { Yasuhiro Matsumura, Ushio Sakaguchi, } \\
\text { Takuo Yamaguchi, Koichiro Togami, } \\
\text { Masanobu Arase, Masanori Kakiuchi, } \\
\text { Kuninori Uemura, Etsuo Murata, } \\
\text { Kenji Yamasaki, Naoki Hagihara, } \\
\text { Kenichiro Nakakuma, Mitsukuni Uchida }\end{array}$ \\
\hline $\begin{array}{l}\text { The Second Department of Surgery, Kumamoto } \\
\text { University, School of Medicine }\end{array}$ & $\begin{array}{l}\text { Masanobu Akagi, Masakazu Matsuda, } \\
\text { Kiyoshi Sakamoto, Noboru Fujino }\end{array}$ \\
\hline
\end{tabular}


で報告する。

\section{II. 研究方法}

\section{1. 対象}

昭和 57 年 12 月から昭和 59 年 3 月の間に Table 1 に示す全国11施設乱よび関連病院24施設, 計35施 設の共同研究機関に入院した患者で， 3 日以上の 抗生剂療法による治療効果が不充分あるいは認め られない年齢16歳以上の重症細菌感染症患者を対 象とした。な抏，免疫グロブリン製剤に対して過 敏症を示したことのある患者, 妊婦拉よび妊娠し ている可能性のある患者, その他主治医が不適当 と判断した患者は対象より除外することとし，原 則として試験に先立ち患者の同意を得ることとし た。

2. 使用薬剤および投与量, 投与方法

SM-4300は 1 バイアル中人免疫グロブリン $\mathrm{G}$ $2500 \mathrm{mg}$ を含有する白色凍結乾燥製剂で，添付の 日局注射用蒸留水 $50 \mathrm{ml}$ で溶解し, 約 30 分かけて ゆっくりと(最初の15分間 $1 \sim 2 \mathrm{ml} /$ 分, その後 $3 \mathrm{ml} /$ 分となるように）点滴静注した. 投与量について は, 臨床症状に応じて, (1) $2500 \mathrm{mg} \sim 5000 \mathrm{mg}$ を 1 回投与，(2) $2500 \mathrm{mg}$ を 1 日 1 回，2 日間連続投 与，（3） $2500 \mathrm{mg}$ を 1 日 1 回，3 日間連続投与し， 最終投与終了日から 7 日間観察することとした。

\section{3. 抗生剂との併用}

原則として最低 3 日間以上同じ抗生剂を投与し ても主要症状の改善が不充分あるいは認められな い患者に対して, その抗生剂の種類, 用法, 用量 などの抗生剂の治療条件を変えずにそのまま継続 し，これにSM-4300を上のせ投与し，SM-4300投 与終了後 3 日以上継続して経過を観察した。な拀, 出来る限り分離菌の検索扣よび抗生剂に対する感 受性を測定した。また，他の免疫グロブリン製剂 扣よび血浆成分を含む製剤の併用は禁止したが， 解熱剂, 副腎皮質ステロイド剂, 抗癌剂々の他の 併用剂の種類，投与量の設定は，対象患者が重症 感染症であることを考慮して，とくに制限を設け ないこととした。

4. 検査扣よび観察項目

体温等の自・他覚症状については原則として SM-4300投与開始 3 日前より毎日その程度を観
察, 記録した。 X 線撮影などの理学的検査および 細菌学的検査については, SM-4300投与前抒よび 投与後に実施することとし，分離菌の同定ならび にその感受性を出来る限り測定した。

臨床検査は原則として SM-4300投与前および 投与後の 2 回実施し, 一般血液検查（赤血球数, 血色素量, ヘマトクリット值, 白血球数, 血小板 数, 赤沈値など), 白血球分画（好中球，好酸球， 好塩基球, リンパ球, 単球など), 肝機能検査 (GOT, GPT, Al-P, LDH ど゙), 腎機能検査 （BUN，血清クレアチニンなど)，尿検査(蛋白, 糖，沈椬など）ならびに CRP, IgG, IgA, IgM, $\mathrm{CH}_{50}, \mathrm{C}_{3}, \mathrm{C}_{4}$ などの值を測定した。

副作用については，SM-4300投与中および観察 期間中に発現した場合は, その内容 (種類, 発現 日，経過，処置，SM-4300との因果関係，併用薬と の因果関係など）について詳細に記録し, 臨床検 查値異常が発現した場合も含めてその後の経過を 追跡調査した。

5. 効果判定（主治医判定）

1) 細菌学的効果

SM-4300投与前後 1 週間以内の分離菌の消長を 基として, 細菌学的効果を陰性化, 減少, 不変, 菌交代，不明の基準で判定した。

2) 臨床効果

SM-4300の最終投与終了後, 1 週間以内の分離 菌の消長, 臨床症状（発熱など）の推移などを総 合して，下記の判定基準に従って主治医が判定し た。但し，臨床効果がみられないものについては SM-4300投与終了 3 日後で無効の判定を行っても よいこととした。

著効：最終投与終了後 $1 \sim 2$ 日以内に主要症状 が消失または著しく改善したもの.

有効：最終投与終了後 $3 \sim 6$ 日以内に臨床症状 が著明に改善したもの.

やや有効：明らかに有効とは判定しがたいが臨 床症状が改善し, 患者の臨床経過に良好な影響を 与えたと考えられるもの.

無効：最終投与終了後 $5 \sim 7$ 日までに臨床症状 の改善が認められないもの。

判定不能：極めて重篤な疾患のため効果判定以 
前に死亡した場合ならびに本剤の適応でないこと が判明した場合など。

3）有用性

臨床効果と安全性（自・他覚的副作用症状, 臨 床検査值異常など）を総合して SM-4300の有用性 について極めて有用，有用，やや有用，有用性な し，判定不能と主治医が判定した.

\section{6. 判定委員会判定}

同時に実施された内科領域扔よび小児領域に抒 けるSM-4300研究会と採用症例の選択条件拈よ び判定基準を統一するために判定委員会（構成メ ンバー：藤井良知, 原 耕平, 西村忠史, 酒井克 治）を構成し，全症例の調査表を詳細かつ厳密に 検討し，以下の基準で症例の採釈を決定した。

1) 対象症例採択の条件

以下のものは除外症例とし, 副作用の解析以外 の解析から除外した。

(i) SM-4300投与開始前 3 日間おょび最終投 与後 3 日間の期間中に, 抗生剂の種類あるいは投 与量を変更したもの.ただし,SM-4300投与前 3 日 間抗生剂が 2 剂以上併用され，抗生剂の種類，投 与量には変更なく, SM-4300投与開始後その抗生 剤のらち一部または全部が中止されても効果判定 が可能と考学られるものは採用とした。

(ii) 抗生剂とSM-4300の投与を同じ日に開始 したもの（同時併用).

（iii）SM-4300投与中に血浆成分を含有する製 剂が併用されたもの。

(iv) SM-4300投与開始後 7 日以内に死亡した
もの. 但し，3 日以上観察され，効果判定が可能 と考学られたものは採用とした。

(v) SM-4300治療対象外疾患と考兄られるも の.

\section{2）効果判定基準}

前述したSM-4300研究会の効果判定基準およ び臨床症状改善の評価に併せて, SM-4300の効果 判定に影響を和よぼすような因子を指摘し，判定 委員会の効果判定が主治医判定と異った時は, 主 治医判定を尊重し，かつ夫々個々の症例について 主治医之検討を重亦た上, 最終的に判定委員会の 判定と主治医の判定に差異が生じないように配慮 した。

\section{III. 成 績}

\section{1. 対象症例}

全国35施設に和いて SM-4300が投与された総 症例数は Table 2に示すと沶り153例であるが, 判 定小委員会に括いては，重症細菌感染症に対する 抗生剂との併用効果について, SM-4300の併用が 有用であることを慎重に検討するために，試験の プロトコールに厳密に合致する症例についてのみ 採用することとし，抗生剤との併用規定違反の症 例, 対象外症例, 併用薬剂禁止規定違反の症例々 の他効果判定が困難と考えられた症例等71例を除 外して82例を解析対象とした。判定委員会に招い て除外された症例は, 抗生剂の併用規定違反 9 例, SM-4300投与開始前およびSM-4300最終投与後 3 日間の期間中に抗生剂の種類叔よび投与量が変 更された 7 例，SM-4300投与開始前 3 日拈よび観

Table 2 Cases administered with SM-4300

\begin{tabular}{|c|c|c|c|}
\hline \multirow{4}{*}{$\begin{array}{l}\text { Total number of } \\
\text { cases administered } \\
\text { with SM- } 4300 \\
\quad 153 \text { cases }\end{array}$} & \multirow{4}{*}{$\begin{array}{l}\text { Evaluable cases } \\
\text { judged by } \\
\text { the Committee } \\
\qquad 82 \text { cases }\end{array}$} & \multicolumn{2}{|l|}{ Reasons for exclusion } \\
\hline & & \multirow{3}{*}{$\begin{array}{l}\text { 1. Diseases out of object } \\
\text { Infections without bacteria or fungi } \\
\text { No evidence of infection }\end{array}$} & 7 \\
\hline & & & 3 \\
\hline & & & 4 \\
\hline & & 2. Protocol deviation & 55 \\
\hline & \multirow{4}{*}{$\begin{array}{l}\text { Excluded case } \\
\text { judged by } \\
\text { the Committee } \\
\quad 71 \text { cases }\end{array}$} & Concomitant antibiotics administration & 9 \\
\hline & & Prophylactic administration & 29 \\
\hline & & $\begin{array}{l}\text { Insufficiency of observation period } \\
\text { for efficacy evaluation }\end{array}$ & 7 \\
\hline & & Combination therapy with other & \\
\hline & & 3. Others & \\
\hline & & Severe underlying disease & 9 \\
\hline
\end{tabular}


察期間中にステロイド剂をたは血浆成分を含む製 剂等が投与された 10 例，SM-4300投与開始 3 日以 内の死亡例で効果判定不能とされた 9 例, 抗生剂 との同時使用開始29例，その他の除外例（対象外 疾患 3 例, 感染症の根拠が薄いと考えられた 4 例 等） 7 例であった。なお，副作用の解析には SM4300の投与された全153例を対象とした。

\section{2. 背景因子}

1）年齢，性別分布

主治医判定执よび委員会判定に打いて解析対象 とした症例の年齢・性別分布を Table 3に示した。 主治医判定の対象患者153例中男77例 (50.3\%), 女76例 $(49.7 \%)$ で, 委員会判定の対象患者 82 例 中男 40 例 $(48.8 \%)$ ，女 42 例 $(51.2 \%)$ で，年齢は 50〜 70歳台が大半を占めて括り, 委員会判定の対 象患者と主治医判定の対象患者の間の年齢分布の 差は認められなかった。

\section{2）疾患別分布}

基礎疾患を, 悪性腫瘍, その他基礎疾患和よび 基礎疾患なしの 3 群に分け，さらに感染診断名を 肺炎, 敗血症 - 敗血症疑, 腹腔内感染症, 肝 - 胆 道系感染症, 尿路感染症, その他感染症に分けて それらの分布をT Table 4, 5に示した. 委員会判定 の解析対象 82 例中, 悪性腫瘍群50例(61.0\%), そ の他基礎疾患群 24 例 (29.3\%), 基礎疾患なし群 8 例 (9.8\%) であった。感染症別では，敗血症・敗 血症疑 13 例 (15.9\%), 腹腔内感染症 29 例 (35.4\%), 肝・胆道系感染症14例 (17.1\%), 肺炎 7 例 $(8.5 \%)$,
Table 3 Background factor (Age \& Sex)

\begin{tabular}{rrrrrrrr}
\hline \multirow{2}{*}{ Age } & \multicolumn{3}{c}{ Total cases } & \multicolumn{3}{c}{ Evaluable cases } \\
\cline { 2 - 7 } & Male & Female & Total & Male & Female & Total \\
\hline$\sim 19$ & 2 & 1 & 3 & 2 & 1 & 3 \\
\hline $20 \sim 29$ & 2 & & 2 & 2 & & 2 \\
\hline $30 \sim 39$ & 3 & 6 & 9 & 2 & 6 & 8 \\
\hline $40 \sim 49$ & 10 & 10 & 20 & 4 & 6 & 10 \\
\hline $50 \sim 59$ & 21 & 17 & 38 & 9 & 8 & 17 \\
\hline $60 \sim 69$ & 20 & 22 & 42 & 14 & 10 & 24 \\
\hline $70 \sim 79$ & 16 & 15 & 31 & 6 & 9 & 15 \\
\hline $80 \sim$ & 3 & 5 & 8 & 1 & 2 & 3 \\
\hline Total (\%) & $(50.3)$ & $(49.7)$ & 153 & 40 & 42 & 82 \\
\hline & & & & & & \\
\hline
\end{tabular}

Table 4 Background factor (Underlying disease)

\begin{tabular}{ccc}
\hline Underlying disease & $\begin{array}{c}\text { Total cases } \\
(\%)\end{array}$ & $\begin{array}{c}\text { Evaluable cases } \\
\text { (\%) }\end{array}$ \\
\hline Malignant tumor & $101(66.0)$ & $50(61.0)$ \\
\hline Other underlying diseases & $41(26.8)$ & $24(29.3)$ \\
\hline Sub-total & $142(92.8)$ & $74(90.2)$ \\
\hline No underlying disease & $11(7.2)$ & $8(9.8)$ \\
\hline Total & 153 & 82 \\
\hline
\end{tabular}

肺化膿症・膿胸 4 例 (4.9\%), その他細菌感染症 8 例 $(9.8 \%)$ で，真菌感染症は 7 例 $(8.5 \%)$ で あった。

\section{3）投与方法}

SM-4300の投与量, 投与回数別の内訳を Table

Table 5 Background factor (Diagnosis)

\begin{tabular}{lcc}
\hline \multicolumn{1}{c}{ Diagnosis } & Total cases (\%) & Evaluable cases (\%) \\
\hline Bacterial infections & $139(90.8)$ & $75(91.5)$ \\
\hline Septisemia, septisemia suspect & $24(15.7)$ & $13(15.9)$ \\
Peritonitis & $45(29.4)$ & $29(35.4)$ \\
Hepato-biliary tract infections & $28(18.3)$ & $14(17.1)$ \\
Pneumonia & $17(11.1)$ & $7(8.5)$ \\
Pulmonary suppuration, pyothorax & $12(7.8)$ & $4(4.9)$ \\
Other bacterial infections & $13(8.5)$ & $8(9.8)$ \\
\hline Fungal infections & $7(4.6)$ & $7(8.5)$ \\
\hline Viral infections & $3(2.0)$ & \\
\hline Others & $4(2.6)$ & 82 \\
\hline \multicolumn{1}{c}{ Total } & 153 \\
\hline
\end{tabular}


Table 6 Background factor (Dosage)

\begin{tabular}{|c|c|c|c|c|c|c|}
\hline \multirow{2}{*}{$\begin{array}{l}\text { Daily } \\
\text { doses } \\
\text { No. }(\mathrm{g}) \\
\text { of times }\end{array}$} & \multicolumn{3}{|c|}{ Total cases } & \multicolumn{3}{|c|}{ Evaluable cases } \\
\hline & 2.5 & 5.0 & Total & 2.5 & 5.0 & Total \\
\hline 1 & 9 & 25 & 34 & 6 & 18 & 24 \\
\hline 2 & 17 & 1 & 18 & 10 & & 10 \\
\hline 3 & 92 & 6 & 98 & 48 & & 48 \\
\hline$>3$ & 1 & 2 & 3 & & & \\
\hline Total & $\begin{array}{c}119 \\
(77.8)\end{array}$ & $\begin{array}{c}34 \\
(22.2)\end{array}$ & 153 & $\begin{array}{c}64 \\
(78.0)\end{array}$ & $\begin{array}{c}18 \\
(22.0)\end{array}$ & 82 \\
\hline
\end{tabular}

6に示した. 判定委員会対象症例 82 例の 1 回投与量 は2.5g 64例 (78.0\%)，5.0g 18例（22.0\%）であ り，交た投与回数別では 1 回投与例 24 例， 2 回投 与 10 例， 3 回投与 48 例で $2.5 \mathrm{~g}, 3$ 回投与が最も多 く, 次いで $5.0 \mathrm{~g}, 1$ 回投与, $2.5 \mathrm{~g}, 2$ 回投与， 2.5 g， 1 回投与の順であった。

\section{3. 主治医判定による臨床効果}

主治医判定による解析対象153例について臨床 効果を検討した結果をTable 7に示した。全例の 臨床効果は著効 12 例 (9.3\%), 有効44例(34.1\%),
やや有効 39 例 (30.2\%), 無効34例 (26.4\%), 判 定不能 24 例で, 判定不能を除く 129 例の有効率は 43.4\%でやや有効を含めると73.6\%の有効率で あった。

1）基礎疾患別臨床効果

基礎疾患を，悪性腫瘍，その他基礎疾患，基礎 疾患なしの 3 群に分けて検討した結果をTable 8 に示した，有効率は覀性腫瘍32.1\% (27/84)，そ の他基礎疾患群 $55.9 \%(19 / 34)$, 基礎疾患な乙群 90.9\% (10/11) であった.

2) 感染症別臨床効果

感染症診断名別臨床効果を Table 9に示した。 判定不能を除いた有効例数 (有効率) は，敗血症・ 敗血症疑 20 例中 9 例 (45.0\%)，腹腔内感染症39例 中 19 例 $(48.7 \%)$, 肝 - 胆道系感染症 23 例中 10 例 (43.5\%)，肺炎 15 例中 5 例 (33.3\%)，肺化膿症・ 膿胸 9 例中 1 例(11.1\%), その他細菌感染症10例 中 5 例 $(50.0 \%)$ で，やや有効を含めると肺炎を 除きいずれも $70 \%$ 以上に有効であった。 また，真 菌感染症 7 例中 4 例 $(57.1 \%)$ に有効で，やや有

Table 7 Clinical effects (Total cases)

\begin{tabular}{|c|c|c|c|c|c|c|c|c|}
\hline \multirow{2}{*}{ Infections } & \multirow{2}{*}{$\begin{array}{l}\text { No. of } \\
\text { cases }\end{array}$} & \multicolumn{5}{|c|}{ Clinical effects } & \multicolumn{2}{|c|}{ Efficacy rate $(\%)^{*}$} \\
\hline & & Excellent & Good & Fair & Poor & Unknown & $\begin{array}{l}\text { Excellent } \\
\text { +Good }\end{array}$ & $\begin{array}{l}\text { Excellent }+ \\
\text { Good }+ \text { Fair }\end{array}$ \\
\hline Bacterial infections & 139 & 12 & 37 & 35 & 32 & 23 & 42.4 & 72.4 \\
\hline Fungal infections & 7 & & 4 & 2 & 1 & & 57.1 & 85.7 \\
\hline Viral infections & 3 & & 2 & 1 & & & 66.7 & 100 \\
\hline Others & 4 & & 1 & 1 & 1 & 1 & 25.0 & 50.0 \\
\hline Total $(\%)^{*}$ & 153 & $\begin{array}{c}12 \\
(9.3)\end{array}$ & $\begin{array}{c}44 \\
(34.1)\end{array}$ & $\begin{array}{c}39 \\
(30.2)\end{array}$ & $\begin{array}{c}34 \\
(26.4)\end{array}$ & 24 & 43.4 & 73.6 \\
\hline
\end{tabular}

* Excluded cases of unknown

Table 8 Clinical effects classified by underlying disease (Total cases)

\begin{tabular}{lcccccccc}
\hline & & \multicolumn{3}{c}{ Clinical effects } & \multicolumn{2}{c}{ Efficacy rate $(\%)^{*}$} \\
\cline { 3 - 9 } Underlying diseases & $\begin{array}{c}\text { No. of } \\
\text { cases }\end{array}$ & Excellent & Good & Fair & Poor & Unknown & $\begin{array}{c}\text { Excellent } \\
\text { +Good }\end{array}$ & $\begin{array}{c}\text { Excellent+ } \\
\text { Good+Fair }\end{array}$ \\
\hline Malignant tumor & 101 & 3 & 24 & 28 & 29 & 17 & 32.1 & 65.5 \\
Other underlying disease & 41 & 5 & 14 & 10 & 5 & 7 & 55.9 & 85.3 \\
No underlying disease & 11 & 4 & 6 & 1 & & & 90.9 & 100 \\
\hline \multicolumn{1}{c}{ Total (\%)* } & 153 & $(9.3)$ & $(34.1)$ & $(30.2)$ & $(26.4)$ & 24 & 43.4 & 73.6 \\
\hline
\end{tabular}

* Excluded cases of unknown 
Table 9 Clinical effects classified by diagnosis (Total cases)

\begin{tabular}{|c|c|c|c|c|c|c|c|c|}
\hline \multirow{2}{*}{ Diagnosis } & \multirow{2}{*}{$\begin{array}{l}\text { No. of } \\
\text { cases }\end{array}$} & \multicolumn{5}{|c|}{ Clinical effects } & \multicolumn{2}{|c|}{ Efficacy rate (\%)* } \\
\hline & & Excellent & Good & Fair & Poor & Unknown & $\begin{array}{l}\text { Excellent } \\
\text { +Good }\end{array}$ & $\begin{array}{l}\text { Excellent }+ \\
\text { Good + Fair }\end{array}$ \\
\hline Bacterial infections & 139 & 12 & 37 & 35 & 32 & 23 & 42.2 & 72.4 \\
\hline Septisemia, septisemia suspect & 24 & 4 & 5 & 5 & 6 & 4 & 45.0 & 70.0 \\
\hline Peritonitis & 45 & 2 & 17 & 11 & 9 & 6 & 48.7 & 76.9 \\
\hline Hepato-biliary tract infections & 28 & 3 & 7 & 7 & 6 & 5 & 43.5 & 73.9 \\
\hline Pneumonia & 17 & 1 & 4 & 4 & 6 & 2 & 33.3 & 60.0 \\
\hline Pulmonary suppuration, pyothorax & 12 & & 1 & 4 & 4 & 3 & 11.1 & 55.6 \\
\hline Other bacterial infections & 13 & 2 & 3 & 4 & 1 & 3 & 50.0 & 90.0 \\
\hline Fungal infections & 7 & & 4 & 2 & 1 & & 57.1 & 85.7 \\
\hline Viral infections & 3 & & 2 & 1 & & & 66.7 & 100 \\
\hline Others & 4 & & 1 & 1 & 1 & 1 & 25.0 & 50.0 \\
\hline Total (\%)* & 153 & $\begin{array}{c}12 \\
(9.3)\end{array}$ & $\begin{array}{c}44 \\
(34.1)\end{array}$ & $\begin{array}{c}39 \\
(30.2)\end{array}$ & $\begin{array}{c}34 \\
(26.4)\end{array}$ & 24 & 43.4 & 73.6 \\
\hline
\end{tabular}

* Excluded cases of unknown

Table 10 Clinical effects (Evaluable cases judged by the Committee)

\begin{tabular}{ccccccccc}
\hline \multirow{2}{*}{$\begin{array}{l}\text { Bacterial or } \\
\text { fungal infections }\end{array}$} & No. of & \multicolumn{3}{c}{ Clinical effects(\%) } & \multicolumn{3}{c}{ Efficacy rate(\%) } \\
\cline { 6 - 10 } & cases & Excellent & Good & Fair & Poor & $\begin{array}{c}\text { Excellent } \\
\text { +Good }\end{array}$ & $\begin{array}{c}\text { Excellent+ } \\
\text { Good +Fair }\end{array}$ \\
\hline Bacterial infections & 75 & 8 & 33 & 19 & 15 & 54.7 & 80.0 \\
\hline Fungal infections & 7 & & 4 & 2 & 1 & 57.1 & 85.7 \\
\hline Total & 82 & $(9.8)$ & $(45.1)$ & $(25.6)$ & $(19.5)$ & 54.9 & 80.5 \\
\hline
\end{tabular}

Table 11 Clinical effects classified by underlying disease (Evaluable cases)

\begin{tabular}{|c|c|c|c|c|c|c|c|}
\hline \multirow[b]{2}{*}{ Underlying disease } & \multirow{2}{*}{$\begin{array}{l}\text { No. of } \\
\text { cases }\end{array}$} & \multicolumn{4}{|c|}{ Clinical effects $(\%)$} & \multicolumn{2}{|c|}{ Efficacy rate(\%) } \\
\hline & & Excellent & Good & Fair & Poor & $\begin{array}{l}\text { Excellent } \\
+ \text { Good }\end{array}$ & $\begin{array}{l}\text { Excellent + } \\
\text { Good + Fair }\end{array}$ \\
\hline Malignant tumor & 50 & $\left(\begin{array}{c}1 \\
2.0)\end{array}\right.$ & $\begin{array}{c}20 \\
(40.0)\end{array}$ & $\begin{array}{c}14 \\
(28.0)\end{array}$ & $\begin{array}{c}15 \\
(30.0)\end{array}$ & 42.0 & 70.0 \\
\hline Other underlying disease & 24 & $\begin{array}{c}4 \\
(16.7) \\
\end{array}$ & $\begin{array}{c}12 \\
(50.0) \\
\end{array}$ & $\begin{array}{c}7 \\
(29.2) \\
\end{array}$ & $\begin{array}{c}1 \\
(4.2) \\
\end{array}$ & 66.7 & 95.8 \\
\hline No underlying disease & 8 & $\begin{array}{c}3 \\
(37.5)\end{array}$ & $\begin{array}{c}5 \\
(62.5)\end{array}$ & & & 100 & 100 \\
\hline Total & 82 & $\begin{array}{c}8 \\
(9.8)\end{array}$ & $\begin{array}{c}37 \\
(45.1)\end{array}$ & $\begin{array}{c}21 \\
(25.6)\end{array}$ & $\begin{array}{c}16 \\
(19.5)\end{array}$ & 54.9 & 80.5 \\
\hline
\end{tabular}

効を含めると， $85.7 \%$ に有効であった。 ウイルス 感染症は 3 例中 2 例有効 $(66.7 \%)$ で 1 例がやや 有効であった。

\section{4. 委員会判定による臨床効果}

委員会判定による解析対象 82 例について, 臨床 効果を検討した結果をTable 10に示した。全例の
臨床効果は著効 8 例 (9.8\%), 有効37例(45.1\%), やや有効21例 (25.6\%), 無効16例 (19.5\%), 有 効率は $54.9 \%$ でやや有効を含めると有効率は 80.5

\%となる。

1）基礎疾患別臨床効果

基礎疾患を覀性腫瘍，その他基礎疾患，基礎疾 
Table 12 Clinical effects classified by diagnosis (Evaluable cases)

\begin{tabular}{lccccccc}
\hline & No. of & \multicolumn{3}{c}{ Clinical effects(\%) } & & \multicolumn{2}{c}{ Efficacy rate(\%) } \\
\cline { 5 - 9 } & cases & Excellent & Good & Fair & Poor & $\begin{array}{c}\text { Excellent } \\
\text { +Good }\end{array}$ & $\begin{array}{c}\text { Excellent+ } \\
\text { Good + Fair }\end{array}$ \\
\hline Septisemia, Septisemia suspect & 13 & 4 & 4 & 2 & 3 & 61.5 & 76.9 \\
Peritonitis & 29 & 2 & 15 & 7 & 5 & 58.6 & 82.8 \\
Hepato-biliary tract infections & 14 & & 7 & 5 & 2 & 50.0 & 85.7 \\
Pneumonia & 7 & & 3 & 1 & 3 & 42.9 & 57.1 \\
Pulmonary suppuration, Pyothorax & 4 & & 1 & 2 & 1 & 25.0 & 75.0 \\
Other bacterial infections & 8 & 2 & 3 & 2 & 1 & 62.5 & 87.5 \\
Fungal infections & 7 & & 4 & 2 & 1 & 57.1 & 85.7 \\
\hline \multicolumn{1}{c}{ Total } & 82 & $(9.8)$ & $(45.1)$ & $(25.6)$ & $(19.5)$ & 54.9 & 80.5 \\
\hline
\end{tabular}

Table 13 Clinical effects classified by dosage

(Evaluable cases)

\begin{tabular}{ccrr}
\hline $\begin{array}{c}\text { No. Daily doses } \\
\text { of times }\end{array}$ & $2.5 \mathrm{~g}(\%)$ & $5.0 \mathrm{~g}(\%)$ & Total (\%) \\
\hline 1 & $5 / 6(83.3)$ & $10 / 18(55.6)$ & $15 / 24(62.5)$ \\
\hline 2 & $5 / 9(55.6)$ & $5 / 9(55.6)$ \\
\hline 3 & $25 / 49(51.0)$ & & $25 / 49(51.0)$ \\
\hline Total & $35 / 64(54.7)$ & $10 / 18(55.6)$ & $45 / 82(54.9)$ \\
\hline
\end{tabular}

患なしの 3 群に分けて検討した結果をTable 11 に示した。有効率は悪性腫瘍群42.0\% (21/50), その他基礎疾患群 $66.7 \%(16 / 24)$, 基礎疾患なし 群は100\%(8/8)であった。やや有効を含めた有効 率は, 悪性腫瘍群 $70.0 \%$, その他基礎疾患群は $95.8 \%$ となる。

また, 感染症診断名別臨床効果を Table 12 に示 した：敗血症・敗血症疑13例中 8 例 (61.5\%)，腹 腔内感染症 29 例中 17 例 $(58.6 \%)$, 肝・胆道系感染 症 14 例中 7 例 (50.0\%), 肺炎 7 例中 3 例 (42.9\%), 肺化膿症・膿胸 4 例中 1 例 $(25.0 \%)$, その他感染 症 8 例中 5 例 $(62.5 \%)$ に有効, 真菌感染症 7 例 中 4 例 $(57.1 \%)$ に有効であり, やや有効を含め ると, 敗血症・敗血症疑 $76.9 \%$, 腹腔内感染症 $82.8 \%$, 肝 - 胆道系感染症 $85.7 \%$, 肺炎 $57.1 \%$, 肺化膿症・膿胸 $75.0 \%$, その他感染症 $87.5 \%$, 真 菌感染症 $85.7 \%$ に有効であった。

2) 投与量別臨床効果

SM-4300の投与量, 投与回数別臨床効果を Table 13に示した。 1 回 $2.5 \mathrm{~g}$ 投与例の有効率は $54.7 \%$
Fig. 1 Relation between clinical effectc and leukocyte counts before SM- 4300 administration

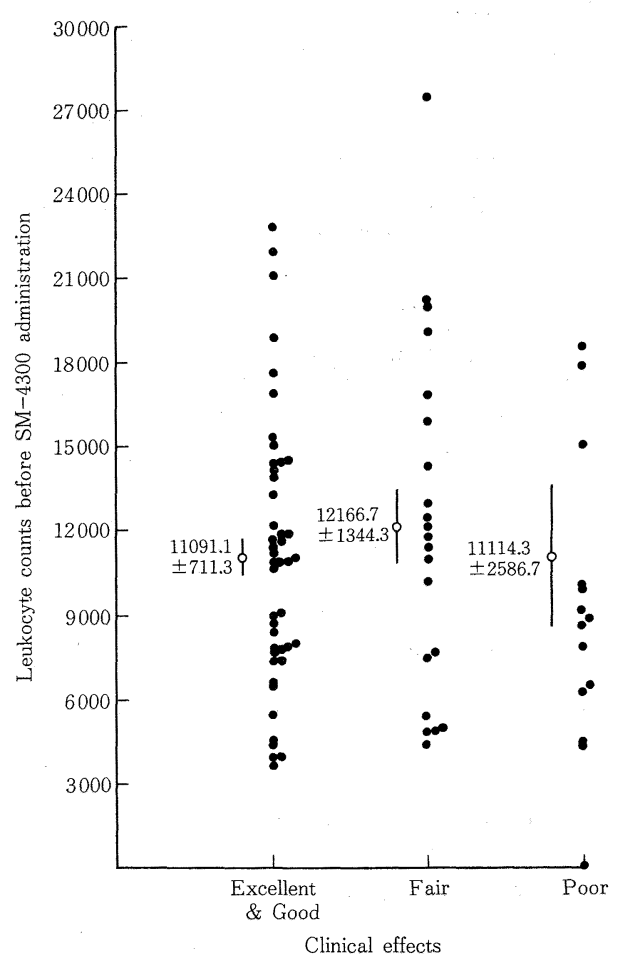

(35/64), 1 回5.0g投与例の有効率は $55.6 \%(10 / 18)$ であり，投与回数別臨床効果は 1 回投与例 $62.5 \%$ $(15 / 24), 2$ 回投与例 $55.6(5 / 9), 3$ 回投与例は 51.0 \%（25/49）であった。

3） SM-4300投与前好中球数別臨床効果

SM-4300投与前の好中球数別臨床効果を Fig. 1 に示した. SM-4300投与前の白血球数あるいは好 
Table 14 Relation between clinical effects and IgG levels before and after SM-4300 administration

\begin{tabular}{|c|c|c|c|c|c|c|c|c|}
\hline \multirow{2}{*}{\multicolumn{2}{|c|}{$\begin{array}{l}\text { IgG levels before and after } \\
\text { SM-4300 administration }\end{array}$}} & \multirow[b]{2}{*}{$\begin{array}{l}\text { No. of } \\
\text { cases }\end{array}$} & \multicolumn{4}{|c|}{ Clinical effects } & \multicolumn{2}{|c|}{ Efficacy rate (\%) } \\
\hline & & & Excellent & Good & Fair & Poor & $\begin{array}{l}\text { Excellent } \\
+ \text { Good }\end{array}$ & $\begin{array}{l}\text { Excellent }+ \\
\text { Good }+ \text { Fair }\end{array}$ \\
\hline \multirow{5}{*}{ Before } & $\sim \geqq 1800$ & 23 & & 4 & 10 & 9 & 17.4 & 60.9 \\
\hline & $<1800 \sim \geqq 800$ & 31 & 2 & 24 & 3 & 2 & 83.9 & 93.5 \\
\hline & $<800 \sim \geqq 200$ & 4 & 1 & 1 & 2 & & 50.0 & 100 \\
\hline & $<200 \sim$ & 0 & & & & & & \\
\hline & Not detected & 24 & 5 & 8 & 6 & 5 & 54.2 & 79.2 \\
\hline \multirow{5}{*}{ After } & $\sim \geqq 1800$ & 29 & 1 & 12 & 10 & 6 & 44.8 & 79.3 \\
\hline & $<1800 \sim \geqq 800$ & 29 & 3 & 17 & 6 & 3 & 69.0 & 89.7 \\
\hline & $<800 \sim \geqq 200$ & 1 & & & 1 & & & 100 \\
\hline & $<200 \sim$ & 0 & & & & & & \\
\hline & Not detected & 23 & 4 & 8 & 4 & 7 & 52.2 & 69.6 \\
\hline
\end{tabular}

中球数と臨床効果の間に，とくに一定の傾向は認 めなかった。

4) SM-4300投与前後の血清 IgG 值と臨床効果

SM-4300投与前後のIgG值を $\geqq 1800,<1800$ $\geqq 800,<800 \sim \geqq 200,<200$ 各群に分けて, SM4300 の投与前および投与後の各群について臨床効 果を検討した結果をTable 14に示した。 SM-4300
投与前の $\operatorname{IgG}$ の值別臨床効果は，とくに一定の傾 向は認めず，投与後の IgG の值別臨床効果につい ても一定の傾向は認められなかった。

5）分離菌別臨床効果招よび細菌学的効果

SM-4300投与前に分離菌が同定された症例は 52 例で, 単一菌感染31例, 複数菌感染21例であった。 これら分離菌を基礎疾患別に Table 15に示した。

Table 15 Clinical isolates

\begin{tabular}{|c|c|c|c|c|c|c|}
\hline Organisms & Septicemia & RTI & Peritonitis & BTI & Others & Total \\
\hline Single infection & 4 & 3 & 10 & 6 & 8 & 31 \\
\hline Mixed infection & & 3 & 6 & 5 & 7 & 21 \\
\hline S. aureus & 1 & & 1 & 1 & 2 & 5 \\
\hline S. epidermidis & & & 2 & 1 & 1 & 4 \\
\hline Streptococcus sp. & & 2 & 4 & & & 6 \\
\hline E. faecalis & & 1 & 6 & 3 & 2 & 12 \\
\hline Other GPC & & & & 2 & 1 & 3 \\
\hline E. coli & 1 & 1 & 2 & & 1 & 5 \\
\hline Klebsiella sp. & 1 & & 1 & 2 & & 4 \\
\hline K. pneumoniae & & & & 1 & & 1 \\
\hline Enterobacter sp. & & 1 & 1 & 1 & & 3 \\
\hline E. cloacae & & 2 & & & & 2 \\
\hline Serratia sp. & 1 & & 1 & & & 2 \\
\hline P. mirabilis & & & 1 & & & 1 \\
\hline Pseudomonas sp. & & 1 & 1 & 1 & 1 & 4 \\
\hline P. aeruginosa & & 1 & 1 & 3 & 2 & 7 \\
\hline Acinetobacter sp. & & & & & 1 & 1 \\
\hline Other GNB & & & 1 & 1 & 2 & 4 \\
\hline B. fragilis & & & 2 & & & 2 \\
\hline Other anaerobes & & & & & 1 & 1 \\
\hline Candida & & 1 & 1 & & 8 & 10 \\
\hline Total & 4 & 10 & 25 & 16 & 22 & 77 \\
\hline
\end{tabular}


グラム陽性菌30株, グラム陰性菌34株, 嫌気性菌 3 株, 真菌10株で, Staphylococcus 属 9 (S. aureus 5), Streptococcus 属 6, (E. faecalis 12, そ
の他 GPC 3, E. coli 5, Klebsiella 属 5, Enterobacter 属 5, Serratia属 2, Proteus 属 1, Pseudomonas 属11 ( $P$. aeruginosa 7 ), Acine-

Table 16 Clinical effects classified by isolated organisms

\begin{tabular}{|c|c|c|c|c|c|c|c|c|}
\hline & \multirow[b]{2}{*}{ Organisms } & \multirow{2}{*}{$\begin{array}{l}\text { No. of } \\
\text { cases }\end{array}$} & \multicolumn{4}{|c|}{ Clinical effects } & \multicolumn{2}{|c|}{ Efficacy rate (\%) } \\
\hline & & & Excellent & Good & Fair & Poor & $\begin{array}{l}\text { Excellent } \\
\text { + Good }\end{array}$ & $\begin{array}{l}\text { Excellent+ } \\
\text { Good + Fair }\end{array}$ \\
\hline \multirow{14}{*}{ 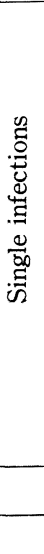 } & S. aureus & 4 & 1 & 1 & 1 & 1 & 50.0 & 75.0 \\
\hline & Streptococcus sp. & 1 & & 1 & & & 100 & 100 \\
\hline & E. faecalis & 6 & & 2 & 3 & 1 & 33.3 & 83.3 \\
\hline & E. coli & 2 & 1 & 1 & & & 100 & 100 \\
\hline & Klebsiella sp. & 4 & 1 & 2 & 1 & & 75.0 & 100 \\
\hline & Enterobacter sp. & 2 & & 1 & 1 & & 50.0 & 100 \\
\hline & Serratia sp. & 2 & & & 1 & 1 & 50.0 & 50.0 \\
\hline & Pseudomonas sp. & 1 & & 1 & & & 100 & 100 \\
\hline & P. aeruginosa & 2 & & 1 & & 1 & 50.0 & 50.0 \\
\hline & Other GNB & 1 & & 1 & & & 100 & 100 \\
\hline & Candida & 6 & & 3 & 2 & 1 & 50.0 & 100 \\
\hline & Sub-total & 31 & 3 & 14 & 9 & 5 & 54.8 & 83.9 \\
\hline & Mixed infection & 21 & 1 & 9 & 7 & 4 & 47.6 & 81.0 \\
\hline & Total & 52 & 4 & 23 & 16 & 9 & 51.9 & 82.7 \\
\hline
\end{tabular}

Table 17 Bacteriological effects classified by isolated organisms

\begin{tabular}{|c|c|c|c|c|c|}
\hline \multirow{2}{*}{ Organisms } & \multirow{2}{*}{$\begin{array}{l}\text { No. of } \\
\text { strains }\end{array}$} & \multicolumn{4}{|c|}{ Bacteriological effects } \\
\hline & & Eradicated & Decreased & Persisted & Unknown \\
\hline S. aureus & 5 & & & 3 & 2 \\
\hline S. epidermidis & 4 & 2 & & 2 & \\
\hline Streptococcus sp. & 6 & 2 & 1 & 3 & \\
\hline E. faecalis & 12 & 3 & 3 & 1 & 5 \\
\hline Other GPC & 3 & & & 1 & 2 \\
\hline E. coli & 5 & 3 & 1 & 1 & \\
\hline Klebsiella sp. & 4 & 2 & & 1 & 1 \\
\hline K. pneumoniae & 1 & 1 & & & \\
\hline Enterobacter sp. & 3 & 1 & & & 2 \\
\hline E. cloacae & 2 & & 1 & & 1 \\
\hline Serratia sp. & 2 & 1 & & & 1 \\
\hline P. mirabilis & 1 & 1 & & & \\
\hline Pseudomonas sp. & 4 & & & 3 & 1 \\
\hline P. aeruginosa & 7 & 1 & & 5 & 1 \\
\hline Acinetobacter sp. & 1 & 1 & & & \\
\hline Citrobacter sp. & 1 & & & 1 & \\
\hline Flavobacterium sp. & 1 & & 1 & & \\
\hline Other GNB & 2 & 1 & & & 1 \\
\hline B. fragilis & 2 & 1 & & 1 & \\
\hline Other anaerobes & 1 & 1 & & & \\
\hline Candida sp. & 10 & 1 & 1 & 5 & 3 \\
\hline Total $(\%)^{*}$ & 77 & $22(38.6)$ & $8(14.0)$ & $27(47.4)$ & 20 \\
\hline
\end{tabular}

* Excluded cases of unknown 
tobacter 1, その他 GNB 4, Bacteroides属 2 , その他の嫌気性菌, 真菌10 (Candida 10) であっ た.

次に, これら分離菌别臨床効果を Table 16に示 した。 単一感染 31 例中 $54.8 \%$, 複数菌感染例 21 例 中 $47.6 \%$ の有効率であり，やや有効を含めると 夫々 $83.9 \%, 81.0 \%$ の有効率であった。

個々の分離菌別にSM-4300投与前後に菌検索 が実施され，菌の消長を追跡し得た 77 株中57株に ついて，これら分離菌別細菌学的効果をT Table 17 に示した。主な分離菌の陰性化率はE. faecalis 42.9\% (3/7), E. coli $60.0 \%$ (3/5), Klebsiella 属75.0\% (3/4), P. aeruginosa $16.7 \%$ (1/6) で, 全体では57株中 22 株 (38.6\%) が消失, 8 株 (14.0\%) が減少，27株 (47.4\%) が不変であった。

6) 副作用

SM-4300の投与された全153例のうち，自・他覚 的副作用の発現した例はなく，臨床検査值異常に ついても，SM-4300 と関係あると考㝋られるもの は認められなかったが，SM-4300との因果関係不 明または疑いありと判定された血清トランスアミ ナーゼ上昇 3 例は副作用発現例として採用した (Table 18).

7）有用性
抗生剂との併用療法に扣けるSM-4300の上の せ効果としての臨床効果に安全性の評価を加えて 主治医が判定した有用性の結果について Table 19に示した。 全症例では153例中124例が判定可能 で極めて有用 8 例 (6.5\%), 有用 48 例 (38.7\%), やや有用 40 例 (32.3\%)，有用性なし28例(22.6\%) であった。採用症例 82 例中極めて有用 6 例 (7.3\%)，有用 39 例 $(47.6 \%)$, や 有用 21 例 $(25.6 \%)$ ，有用性なし16例 $(19.5 \%)$ で有用率は $54.9 \%$ ，やや有用以上を含めると $80.5 \%$ の有用率 であった。

\section{IV. 考 察}

SM-4300は既に述べたように，生体内で血浆中 に存在する天然のグロブリンと同様の効果を発揮 乙得ると考えられる非修飾のいわゆる intactの

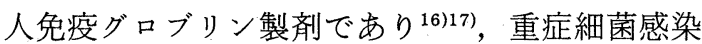
症に対し，抗生剂との併用効果を期待し得るもの と考兄られ，前臨床試験成績，外国に括ける第一 相臨床試験成績，さらに本邦に抢ける第一相臨床 試験成績 ${ }^{18)}$ よその安全性についても問題ないと 考号れたので，SM-4300研究会に执いて全員の 了解を得て試験を実施した。

人免疫グロブリン製剤については，低または無 ガンマグロブリン血症の補充療法はもとより, 重

Table 18 Side effects

\begin{tabular}{lccc}
\hline \multicolumn{1}{c}{ Side effect } & $\begin{array}{l}\text { No. of } \\
\text { cases }\end{array}$ & $\begin{array}{l}\text { Causal relation } \\
\text { wIth SM-4300 }\end{array}$ & $\begin{array}{l}\text { Causal relation } \\
\text { with combined } \\
\text { antibiotics }\end{array}$ \\
\hline Elevation of GOT, GPT, Al-P & 1 & Unknown & Unknown \\
Elevation of GOT, GPT & 1 & Unknown & Unknown \\
Elevation of GOT, GPT & 1 & Doubtful & Unknown \\
\hline
\end{tabular}

Table 19 Clinical usefulness on SM-4300

\begin{tabular}{ccccccccc}
\hline & & \multicolumn{3}{c}{ Usefulness } & & Utility rate $(\%)^{*}$ \\
\cline { 3 - 9 } & $\begin{array}{c}\text { No. of } \\
\text { cases }\end{array}$ & $\begin{array}{l}\text { Excellent } \\
\text { useful }\end{array}$ & $\begin{array}{l}\text { Good } \\
\text { useful }\end{array}$ & $\begin{array}{l}\text { Fairly } \\
\text { useful }\end{array}$ & Useless & Unknown & $\begin{array}{c}\text { Excellent } \\
+ \text { Good } \\
\text { useful }\end{array}$ & $\begin{array}{c}\text { Excellent } \\
+ \text { Good } \\
+ \text { Fairly } \\
\text { useful }\end{array}$ \\
\hline $\begin{array}{c}\text { Total cases } \\
(\%)^{*}\end{array}$ & 153 & $\begin{array}{c}8 \\
(6.5)\end{array}$ & $\begin{array}{c}48 \\
(38.7)\end{array}$ & $\begin{array}{c}40 \\
(32.3)\end{array}$ & $\begin{array}{c}28 \\
(22.6)\end{array}$ & 29 & 45.2 & 77.4 \\
\hline $\begin{array}{c}\text { Evaluable cases } \\
(\%)^{*}\end{array}$ & 82 & $(7.3)$ & $(47.6)$ & $\begin{array}{c}21 \\
(25.6)\end{array}$ & $\begin{array}{c}16 \\
(19.5)\end{array}$ & 54.9 & 80.5 \\
\hline
\end{tabular}

* Excluded cases of unknown 
症細菌感染症に対する抗生剤との併用療法におい て臨床効果が期待し得ることはよく知られてい る19) 21). とくに白血病, 悪性腫瘍, あるいはステ ロイド剂，制癌剂，免疫抑制剂の投与時にみられ る免疫不全状態は医原性免疫不全あるいは続発性 免疫不全として, 生体の感染防御機能を低下せし め, 易感染状態の下でしばしば感染症を重症化し, 抗生剂の効果が認められないことが多(22) 24). 外 科領域に掞いては，さらに手術侵襲による障害が 重なり感染症の治癒は遷延化する傾向にある。こ れらの重症細菌感染症に掞いて, 人免疫グロブリ ン製剂の抗生剂との併用療法による効果が期待し 得ることは種々の基礎的検討からも知られてい る25) 28). しかしながら，臨床面に拈いては，これ ら病態の多様性と抗生剂治療が認められない場合 に抢ける上のせ効果を期待するという点で, 人免 疫グロブリン製剤の効果判定を的確に行らことは 難しく, 慎重かつ厳密な判定基準による検討が必 要である ${ }^{29)}$.このような点から, 今回われわれは統 一プロトコールにより, 重症細菌感染症に対する SM-4300 と抗生剂との併用効果について多施設共 同研究により, 抗生剤との併用規定, 観察方法, 評価方法について一定の規準を定め，各施設にお ける対象疾患の選択, 評価方法に出来るだけ差異 の生じないよう配慮するとともに, 同時期に実施 された内科, 小児科領域に打ける研究会と共通の 評価を行らため, 判定小委員会に拈いて一定の判 定規準に基づく症例の選択, 効果判定を行い, 本 論文では主として判定委員会判定による集計・解 析を行った。

全国35施設に打いてSM-4300が投与された総 症例数は153例であり, 主治医判定に打ける臨床効 果は有効率 (有効以上) $43.4 \%$ で，やや有効を含 めると $73.6 \%$ の有効率であった。判定委員会に抒 いては, ウイルス感染症や感染症状の不明確な症 例を除き, 重症細菌感染症に限定して解析するこ ととし，さらに可能な限り客観的に SM-4300の効 果を検討するために, 抗生剂の併用規定違反の症 例，血浆成分を含む製剂等その他の併用薬規定違 反の症例等 71 例を解析対象から除外して, プロト コールに厳密に合致し，SM-4300の上のせ効果を
評価し得る症例のみを採用した。判定委員会採用 症例 82 例に和ける臨床効果は有効率 $54.9 \%$ で, や や有効を含めると $80.5 \%$ の有効率であった。一般 的に化学療法剤の有用性の判定について慣用され た有効率は, 著効と有効を併せて算出した有効率 であるが，人免疫グロブリン製剂の試験に拉いて は，対象疾患が前者の場合と異り，難治性または 遷延した感染症が多く, さらにすべて重症化した 感染症であり，抗生剂が 3 日以上投与されても効 果の認められない症例に限られる。したがって SM-4300の併用効果を観察するに当っても, やや 有効程度の効果をみたものも臨床的に意義がある と考えられたので併記した。

基礎疾患別臨床効果については, 悪性腫瘍群の 有効率が $42.0 \%$ と低い傾向にあったが，やや有効 以上では $70.0 \%$ の有効率で, その他の基礎疾患群 では有効率 $66.7 \%$, やや有効以上 $95.8 \%$, 基礎疾 患なし群では有効率 $100 \%$ と高かった。 なた, 感染 診断名別臨床効果については, 敗血症・敗血症疑 例に拈いて $61.5 \%$ (やや有効以上 $76.9 \%$ ), 腹腔内 感染症 $58.6 \%(82.8 \%)$, 肝・胆道感染症 $50.0 \%$ ( $85.7 \%)$, 肺炎 $42.9 \%$ ( $57.1 \%)$, 肺化膿症・膿胸 $25.0 \%(75.0 \%)$, その他細菌感染症62.5\% (87.5 $\%$, 真菌感染症 $57.1 \%(85.7 \%)$ の有効率で肺炎 を除いたすべてにすぐれた成績を示した。

一方, これら重症細菌感染に打いては, 感染の 種類や起炎菌が複雑多様であること, 人免疫グロ ブリン製剂の作用機序は細菌に対する直接的な作 用ではなく, 白血球貧食能の増強作用, Phagocytosis に対する抗体活性作用等補体系内の制御 にあることから抗生剂の抗細菌学的作用と若干お もむきが異るが, 抗生剂無効症例への上のせ効果 として判定し得た 57 株中 22 株 $(38.6 \%$ ) に消夫, 8 株 (14.0\%) に減少と細菌学的効果が認められ たことは特記すべきと考兄られる。

人免度グロブリン製剤の投与期間は 1 日 1 日, 1 ～ 2 日せいぜい 3 日間でそれ以上投与する必要 は少ないと考兄られているが，今回の SM-4300の 研究に括いても上記投与期間を設定して試験を実 施した. 1 回投与量は $2.5 \mathrm{~g} 64$ 例掞よび5.0g 18例 で $2.5 \mathrm{~g}$ 投与例が多く, 投与回数は 3 回投与が最も 
多く 49 例，次いで 1 回投与 24 例， 2 回投与 9 例と 外科領域に括ける一般的使用量を反映しているも のと考学られる。な抢，投与量別の臨床効果につ いて，とくに一定の傾向は認められなかったこと は, 対象疾患の重症度等により使用量が決定され たためと考えられた。

白血球数, 好中球数, 血中 IgG 值等は感染症に 治療上重要な影響を与えられると考えられが， SM-4300投与前あるいは投与後のこれらの值と臨 床効果の関係を検討した結果, 投与前の白血球数, 好中球数の值は, SM-4300の臨床効果ととくに関 係は認められず，むしろ感染症の重症度と関係が あるものと考えられた，血中 IgG 值についても， SM-4300投与前後に拈いて全体として上昇の傾向 が認められたが，SM-4300投与前あるいは投与後 の血中 IgG 値と SM-4300の臨床効果の間にも一 定の傾向は認められなかった。

副作用に関しては, SM-4300の投与された全153 例について検討したが，SM-4300 と関係があると 思われる自・他覚的副作用を現わした症例は 1 例 もなく，血清トランスアミナーゼの上昇例 3 例が SM-4300との因果関係を否定出来ないものとして 取り上げた。これら副作用についてはいずれも軽 微なもので発現頻度も低く, 対象疾患の重症度を 考えると SM-4300の安全性を危惧するものでは なかった。

以上の成績から外科額域に拈ける重症細菌感染 症に対し, SM-4300は抗生剂と併用した場合, 従来 報告されている人免疫グロブリン製剤の成績と比 較しても満足すべき臨床効果, 細菌学的効果が期 待出来るものと考兄られ, 安全性も高、薬剤とし て臨床使用に充分耐光得るものと考兄られる。

\section{文献}

1) Fisher, M.W.: Synergism between human gammaglobulin and cholramphenicol in the treatment of experimental bacterial infections. Antibiot. Chemother., $7: 315,1957$.

2) Waisberm, B.A.: Thd treatment of bacterial infections with the combination of antibiotics and gamma globulin. Antibiot. Chemother., 7 : 322, 1957.

3) Fisher, M.W. \& Mannig, M.C.: The specific antibody nature of the therapeutic action of gamma globulin in experimental bacterial infections in mice. Antibiot. Ann., $1957: 572,1958$.

4) Mannig, M.C., et al.: The therapeutic activity of gammaglobulin. Chlorampheniciol combinations in mouse infections due to Salmonella,Pneumococci, Escherichia coli or Pasteurella. Antibiot. Ann., 1958 : 566, 1958.

5) Martin Du Pan, et al.: Das Verhalten der intramüskular, intravenös und per os verarbreichen Gammaglobulin. Blut, 5 : 104, 1959.

6) Janeway, C.A.: The plasma proteins: Their Functions and Clinical uses. Pediatrics, $2: 489$, 1948.

7) Barandum, S., et al.: Zur Frage der intravenösen Gammaglobulin-Applikation. Helv. Med. Acta, 36 : 551, 1961.

8) Schultze, H.E. \& Schwick, G. : Neue Möglichkeiten Intravenöser Gammaglobulin-Applikation. Deutche Med. Wochnschrift, 87: 1463, 1966.

9) Koblet, H.: Turnover of standard gamma globulin, $\mathrm{pH} 4$ gamma globulin and pepsin disaggregated gamma globulin and clinical implications. Vox.Sang., 13: 93, 1967.

10) Janeway, C.A.: Intravenous gammaglobulin. new Engl. J. Med., 278: 919, 1968.

11) Masuho, Y., Tomibe, K., Watanabe, T., et al. : Development of an intevenous $\gamma$-globulin with Fc activities. Vox. Sang., 32: 175-290, 1977.

12) Chun, P.W., Fried, M. \& Ellis, E.F.: Use of watersoluble polymers for the isolation and purificatio of human immunoglobulins. Analytical Biochem., 19 : 481, 1967.

13) Polson, A. \& Ruiz-Bravo, C.: Fractination of plasma with polyethylene Glycol. Vox. Snag., $23: 107,1972$.

14）藤井良知他 (Venglobulin-I 研究会)：重症感染症 に対する Venglobulin-Iの使用経験. ヴェノグロ ブリン-I医学文献集一臨床編 I一. 医学書房, $1-22,1980$.

15) Cohn, E.J.: A system for the separation of the compounds of human blood: Quantitative procedures for the separation of the protein components of human plasma. J. Am. Chem. Soc., $72:$ 465, 1950.

16) Alpern, M., Stretch, M.A. \& Hooper, J. : Enhancement of Opsophgocytosis of Opprtunistic Bacterial pathogens by Intravenous Gamma Globulin. 21st Interscience Conference on Antimicrobial Agents and Chemotherapy. Chicago, november, 1981.

17) Hooper, J., Mankarious, S., Garciacelay, Z., et 
al. : Purification and Properties of Normal Human IgG Suitable for Intravenous Injection. Annual meeting of the American Society for Microbiology, 1981.

18）SM-4300概要：乾燥イオン交換樹脂処理人免疫グ ロブリン，住友化学工業(株), 日本トラベノール (株)

19）藤井良知：感染症のガンマグロブリン療法. Medical Postgraduates, $17: 174-181,1979$.

20）早川 浩：重症感染症におけるガンマグロブリン 療法. 最新医学, 34(7)：1442-1448, 1979.

21）早川 浩：免疫不全症の感染の免疫学的予防と治 療。最新医学, 37(5)：918一928, 1982.

22) Graham, C.W.: Immunological and carcinogenic side effects of anesthesia. Intern. Anesthesiol. Clinics, 18: 173, 1980.

23）平澤博之, 小林弘忠, 大竹喜雄, 他: 多臓器障害 (multiple organ faillure) の病態と治療. 外科, $44:$ 927-932, 1982.
24）高橋秀仁，永島 裕：医原性免疫不全, 薬物によ る免疫不全.免疫と疾患, 6(6)：855-858, 1983.

25）砂川慶介，秋田博伸，他：実験的感染症に対する 静注用免疫グロブリン製剂の効果一抗生物質との 併用実験を中心として一. 感染症学雑誌, 56(2)： 1196-1202， 1982.

26）重野芳輝, 猿渡勝彦, 他：実験的マウス縁膿菌感 染症に対するガンマグロブリン製剂の効果. 感染 症学雑誌, 57(6)：531-536, 1983.

27）真下啓明：内科および外科領域における重症感染 症に対する静注用人免疫グロブリン (GV-523) と 抗生剂との併用効果. 感染症学雑誌, 57(8)： $724-749,1983$.

28）重野芳輝：難治性慢性気道感染症に対するガンマ グロブリン補助療法. 感染症学雑誌, 57(8): $662-675,1983$.

29）藤井良知：血液製剂特に血漿分画製剂の評価法に 関する研究. 医薬品研究, 15(2)：317-331, 1984.

Therapeutic Effects of SM-4300, Antibiotics Combinations Against Severe Bacterial Infections in the Field of Surgery

\section{Katsuji SAKAI*}

The Society for Clinical Evaluation on SM-4300

*The Second Department of Surgery, School of Medicine, Osaka City University

A newly developed human immunoglobulin, SM-4300, purified by ion-exchange adsorption, has been studied in the surgical field.

SM- 4300 has been evaluated clinically in patients with severe infections in the combined use with the antibiotics.

1. 153 patients were treated with SM-4300 and evaluated by doctors in charge. Clinical effects were excellent in 12 cases, good in 44, fair in 39, poor in 34 and unknown in 24 .

2. Out of 153 cases 82 were accepted as the evaluable cases by the committee. These cases consisted of septicemia in 13 cases, peritonitis in 29, hepato-biliary tract infections in 14, pneumonia in 7 , pulmonary suppuration and pyothorax in 4 and others. The majority of patients $(90.3 \%)$ had one or more underlying diseases.

3. Clinical effects of SM-4300 were excellent in 8 cases $(9.8 \%)$, good in $37(45.1 \%)$, fair in 21 $(25.6 \%)$ and poor in $16(19.5 \%)$. The efficacy rate was summarised as $54.9 \%$.

4. 57 strains from 52 cases of clinical isorates were evaluable for bacteriological effects which were eradicated in 22 strains, decreased in 8 and persisted in 27.

5. No clinical side effects were obserbed. 